\title{
Association of depression with chewing problems in Koreans : A cross-sectional study using the Korea National Health and Nutrition Examination Survey 2016
}

\author{
Chan Mo Yang ${ }^{1,2}$, Ju Won Baek ${ }^{3 *}$ \\ 'Division of Child and Adolescent Psychiatry, Department of Psychiatry, Seoul National University Hospital, Seoul, Republic of Korea \\ ${ }^{2}$ Korea Brain-Behavior Mental Health Institute, Iksan, Republic of Korea \\ ${ }^{3}$ Dental Clinic Center, ChungBuk National University Hosptial, Cheongju, Republic of Korea
}

\begin{abstract}
Purpose: This study was designed to analyze the relationship between the presence and severity of depression and chewing problems (CPs) in a representative sample of the general population. Materials and Methods: Health surveys and examinations were conducted on a nationally representative sample $(n=8150)$ of Korean was conducted. CPs was determined by a simple survey response concerning "Do you feel uncomfortable about chewing your food because of problems with your mouth such as teeth, dentures and gums?" Depression was defined as individuals with a total score $\geq 10$ on the Patient Health Questionnaire (PHQ)- 9 survey. Data regarding demographics, socioeconomic history and comorbid health conditions were used to analyze adjusted logistic regression models. Results: In the Korean population, the prevalence of depression was significantly greater in individuals with $\mathrm{CP}$ $(17.2 \%)$ than in those without CP (10.2\%). On multivariate logistic regression analysis, the presence of depression was significantly associated with CPs (adjusted odd ratio [aOR]: 1.90, $P<0.001$ ). The risk of CPs increased with increasing severity of depression as follows: severe depression (OR: 2.62, $P<0.001$ ), moderately severe depression (OR: $2.19, P<0.001)$. Conclusion: The presence of depression was significantly associated with CPs, especially in severely depressed individuals. Depression screening should be considered in treating CP patients. (J Dent Rehabil Appl Sci 2020;36(1):12-20)
\end{abstract}

Key words: depression; the Korea National Health and Nutrition Examination Survey (KNHANES); chewing problem; prevalence; risk factors; general population

\section{서론}

씹을 수 있는 능력은 구강 기능의 핵심적인 측면으로, 성인의 일상 생활에서 중요한 능력이다. ${ }^{1}$ 씹기 불편감은 구강 건강 저하의 기본적인 지표로, 삶의 질과 기능 수준 (functional status)에 영향을 미치는 주요 공중보건 문제 이다. ${ }^{1,2}$ 씹기 불편감은 음식을 선택하여 저작하는데 있어 환자의 주관적인 불편 증상 또는 객관적인 불편감으로 정의할 수 있다. ${ }^{3}$ 씹기 불편감은 구강점막장애, 연하곤란,

*Correspondence to: Ju Won Baek

Clinical Assistant Professor, Dental Clinic Center, ChungBuk National University Hosptial, 1Sunhwan-ro 776, Seowon-gu, Cheongju, 28644, Republic of Korea

Tel: +82-43-269-6295, Fax: +82-504-057-5833, E-mail: maesbaek@naver.com

Received: December 11, 2019/Last Revision: January 2, 2020/Accepted: January

2,2020
구강건조증, 무치악 상태 증가 및 치통 등의 구강 문제와 직접적으로 관련되나, 골다공증, 신경계 질환의 유병률 증가와 같은 다른 전신적, 환경적 요인에 의해서도 영향 을 받는다. ${ }^{4-6}$ 저작 능력은 삶의 만족도와 연관이 있음이 알려져 있다. ${ }^{7}$ 하지만 씹기 불편감을 호소하는 환자들 대 부분이 치과로 내원하기 때문에 우울감과 같은 정신적인 문제는 보통 다뤄지지 않는다. 선행 연구들에 따르면 정 신질환이 씹기 불편감과 연관된다는 점이 확인되었다. 6,8 정신과적 질환 중에서도 우울증은 씹기 불편감과 종종

Copyright $@ 2020$ The Korean Academy of Stomatognathic Function and Occlusion. (c) It is identical to Creative Commons Non-Commercial License. 
연관되며, 씹기 불편감을 증가시키는 위험요소로 간주된 다. ${ }^{2,9}$ 하지만 현재까지 일반인 대상으로 선별검사 도구를 이용해 우울증을 평가하고 씹기 불편감과의 관련성을 분 석한 연구는 부족하다.

이에 본 연구는 국민건강영양조사 제 7 기 1 차년도 (2016)의 자료를 이용하여 한국 성인을 대상으로 씹기 불 편감 및 우울증에 대한 자가보고형 설문지를 통해 지역 사회 일반 인구의 대표성 있는 집단에서 우울 증상과 씹 기 불편감과의 관계를 조사하였다. 그리고 씹기 불편감 유무에 따른 우울증 유병률을 분석하고, 일반인에서 우 울증이 씹기 불편감에 위험 요소로 작용하는지를 평가하 였다.

\section{연구 재료 및 방법}

\section{연구 모집단 및 샘플링}

2016년에 한국 국민건강영양조사 제7기 제1차년도 (the Korea National Health and Nutrition Examination Survey (KNHANES) version VII-1)에서 수행된 데이 터를 분석하였다. 한국 질병관리본부(the Korea Centers for Disease Control and Prevention (KCDC))에서 매년 분석하는 KNHANES는 대한민국 가구(원)의 건강 및 영양 상태를 파악하도록 디자인되었다. 지역, 성별, 연령
을 기준으로 비례하여 분류된 대한민국 국민들을 기반으 로 1998년부터 시행된 전국적 다단계 군집 층화 임의 추 출을 거친 조사 방법이다.

조사 참여자들은 매년 변화되었으며, 연속되어 모니터 되지 않았다. 조사는 설문지를 이용한 건강 설문조사, 검 진 조사와 훈련된 인터뷰어, 의료 스텝, 연구원이 시행하 는 영양 조사, 세가지 부문으로 구성되었다..$^{10}$ 우울증선 별도구(The Patient Health Questionnaire (PHQ))는 우 울증 선별 검사 도구로 사용되는 우울 장애의 기준 기반 진단 도구로서, 국민건강영양조사 성인 참여자에게 실시 되었다. 국민건강영양조사 제7기 1차년도(2016) 설문 및 검진조사는 8150 명의 참여자에게 시행되었으며. 한국질 병관리본부의 임상연구심의위원회로부터 승인을 받았 다. 설문 조사에 참여한 모든 참가자에게 서면 동의서를 받았다. 본 분석은 씹기 불편감 조사에 응답하고 PHQ-9 및 공분산(covariance)에서 결측값이 없는 19세 이상 성 인 6128명의 응답자에 국한하여 시행하였다(Fig. 1).

\section{씹기 불편감과 우울증의 정의}

씹기 불편감 호소 환자들은 이번 조사에서 ‘현재 치아 나 틀니, 잇몸 등 입안의 문제로, 음식을 씹는 데에 불편 감을 느끼십니까?’라는 질문에 “매우 불편함, 불편함”으 로 응답한 사람들로 정의하였다.

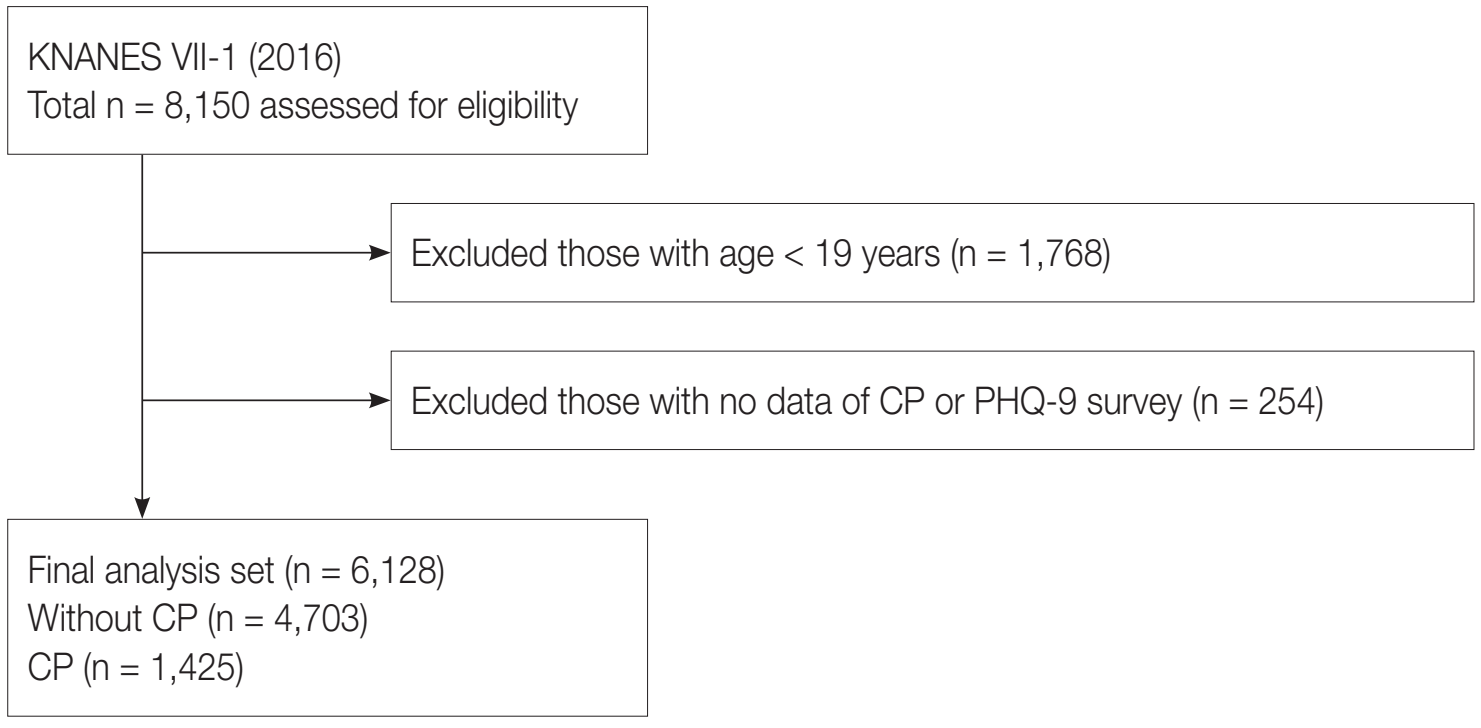

Fig. 1. Flow diagram of inclusion and exclusion of participants in this study from the 2016 Korea National Health and Nutrition Examination Surveys (KNHANES VII-1). CP indicates chewing problems; PHQ, Patient Health Questionnaire. 
우울증은 우울증선별도구(PHQ-9) 총점 27점 중 10 점 이상인 대상자로 정의하였다. ${ }^{11}$ 간단한 9 가지 질문으 로 구성되어 신뢰롭고 타당한 우울증 심각도 측정방법 인 PHQ-9는 우울 증상을 조사하는데 사용되어왔다. ${ }^{12-14}$ PHQ-9 설문지는 DSM-IV (depression criteria from 4th edition of diagnostic and statistical manual of mental disorders)를 기반으로 하고 지난 2주 동안 환자의 우울 증상에 대해 질문한다. 응답은 각 항목에 대해 "0"(전혀 아니다)부터 “3”(거의 매일)까지 이다. ${ }^{12,14}$ 총 PHQ-9 점 수는 0 부터 27 까지 분포하며, 높은 점수일수록 severe 우울 증상을 나타낸다. 이전 연구들에 의하면, 이 방법 은 주요 우울증에 대한 높은 민감도(sensitivity)와 특이 도(specificity)를 보이기 때문에, PHQ-9 점수 10점 이상 은 우울증의 발현을 나타내는 것으로 간주된다. ${ }^{12,14}$ 이번 연구에서 PHQ-9 점수 10점을 우울증의 발현으로 분류 하였다. 우울증 정도(The levels of depression)는 PHQ9 점수에 따라 none (0 - 4), mild (5 - 9), moderate (10 14), moderately severe (15 - 19), severe (20 - 27)로 분류 하였다. ${ }^{14}$

\section{인구 통계 및 사회경제적 상태, 병력, 생활습관 등 변수에 대한 설명}

우리는 건강 설문 조사, 검진 조사를 이용하여 참여자 들의 인구 통계학적 특성, 사회경제적 상태, 병력(예; 고 혈압, 당뇨 등), 생활습관을 분석하였다. 모든 참여자들 에게 고혈압, 당뇨, 고지혈증, 심근경색, 뇌경색, 만성신질 환, 간경변과 같은 주요 동반질환에 대해 의사의 진단을 받았는지 여부를 조사하였다.

가구 소득 수준은 사분위로 그룹화되었다. 교육 수준 은 6년(초등학교), 7 - 9년(중학교), 10 - 12년(고등학교), 13년 이상(대학교), 4 가지 그룹으로 분류하였다. 체질량 지수(BMI)는 체중을 신장 제곱으로 나눈 값으로 계산하 였다. 흡연 상태는 비흡연자, 과거 흡연자, 현재 흡연자로 분류했고, 음주상태는 문제 음주 유무로 분류하였다.

\section{통계 분석}

임상적 특성은 씹기 불편감이 있는 사람과 없는 사람 사이에서 비교되었다. Student t test을 사용하여 연속 변 수를 비교하고 $\chi^{2}$ test를 범주형 변수에 사용하였다. 씹기 불편감, 우울증 및 우울증의 심각도와 관련된 요인들을
식별하기 위해 다중 로지스틱 회귀 분석을 수행하였다. ORs (Odds ratios)은 이에 상응하는 95\% 신뢰구간(CI) 에 따라 계산되었다. 교란변수(confounding variables) 로 인한 연관성을 배제하기 위해 세 가지 다른 모델을 사 용하여 다중 로지스틱 회귀 분석이 수행되었다. Model 1 은 조정되지 않았고, Model 2는 연령과 성별에 따라 조 정되었고, Model 3는 연령, 성별, 가구 소득, 교육 수준, 음주, 흡연, BMI 및 동반 질환과 같은 기타 환경 요인에 의해 조정되었다. 통계 분석은 SPSS 23.0 (IBM Corp., Armonk, USA)를 사용하여 시행하였고, two-sided $P$ values $<0.05$ 은 통계적으로 유의한 것으로 간주하였다.

\section{결과}

2016년 씹기 불편감 유병률은 19세 이상 한국인 성인 참여자에서 $23.3 \%$ 로, 남성은 $44.4 \%$, 여성은 $55.6 \%$ 의 유 병률을 나타냈다. 우울증의 유병률은 씹기 불편감이 없 는 사람들 $(10.2 \%)$ 보다 씹기 불편감이 있는 사람들에서 유의하게 더 높았다(17.2\%) $(P<0.001$, Fig. 2). 우울증 심각도는 씹기 불편감이 없는 사람들보다 씹기 불편감이 있는 사람들이 더 심했다 $(P<0.001)$. 연령, 가구소득, 교 육 수준, 흡연, 고혈압, 당뇨, 고지혈증, 심근경색, 뇌경색, 만성신질환, 간경변과 같은 동반질환이 씹기 불편감과 연관되었다(Table 1).

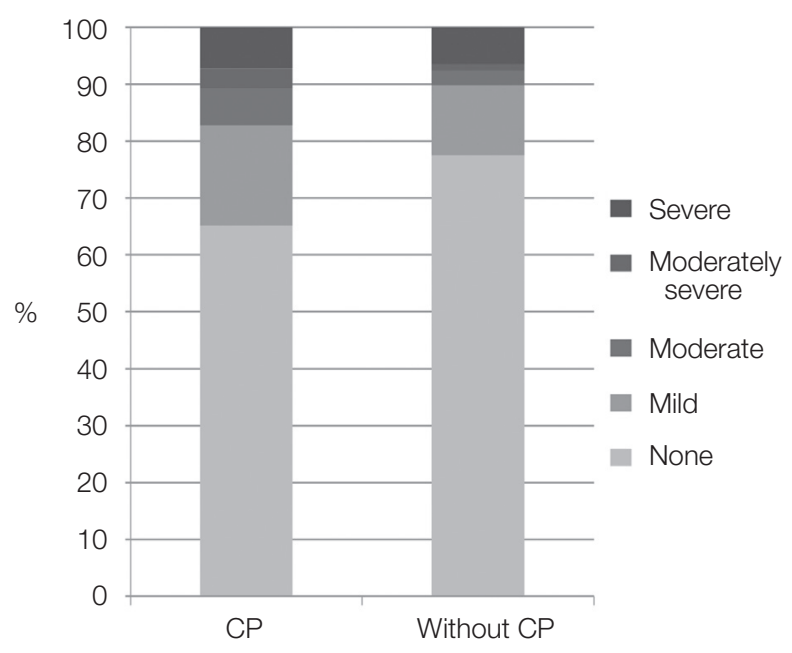

Fig. 2. The prevalence of depression was significantly greater $(17.2 \%)$ in individuals with CP than those without CP $(10.2 \%)(P<0.001)$. CP indicates chewing problems. 
Table 1. Characteristics of the study population according to chewing problem

\begin{tabular}{|c|c|c|c|c|}
\hline \multicolumn{2}{|c|}{ Variables } & \multirow{2}{*}{$\begin{array}{l}\text { Without CP } \\
(\mathrm{n}=4442) \\
48.0(16.2)\end{array}$} & \multirow{2}{*}{$\begin{array}{c}\begin{array}{c}\text { With CP } \\
(\mathrm{n}=1360)\end{array} \\
61.1(14.9)\end{array}$} & \multirow{2}{*}{$\begin{array}{c}P / \chi^{2} \\
<0.001\end{array}$} \\
\hline Age & & & & \\
\hline \multirow[t]{2}{*}{ Sex } & Male & $2014(42.8 \%)$ & $633(44.4 \%)$ & \\
\hline & Female & $2689(57.2 \%)$ & $792(55.6 \%)$ & \\
\hline BMI* & & $23.9(3.5)$ & $24.1(3.6)$ & 0.039 \\
\hline \multirow[t]{5}{*}{ Level of depression } & None $(0-4)$ & $3645(77.5 \%)$ & $929(65.2 \%)$ & $<0.001$ \\
\hline & Mild (5-9) & $580(12.3 \%)$ & $252(17.7 \%)$ & \\
\hline & Moderate $(10-14)$ & $123(2.6 \%)$ & $92(6.5 \%)$ & \\
\hline & Moderately severe (15 - 19) & $56(1.2 \%)$ & $50(3.5 \%)$ & \\
\hline & Severe $(20-27)$ & $299(6.4 \%)$ & $102(7.2 \%)$ & \\
\hline \multirow[t]{3}{*}{ Smoking status } & Non-smoker & $2975(63.3 \%)$ & $778(54.6 \%)$ & $<0.001$ \\
\hline & Ex-smoker & $919(19.5 \%)$ & $326(22.9 \%)$ & \\
\hline & Current smoker & $809(17.2 \%)$ & $321(22.5 \%)$ & \\
\hline \multirow[t]{2}{*}{ Problematic Alcohol Consumption } & None & $4129(87.8 \%)$ & $1273(89.3 \%)$ & $<0.115$ \\
\hline & Yes & $574(12.2 \%)$ & $152(10.7 \%)$ & \\
\hline \multirow[t]{4}{*}{ Household income } & Low & $718(15.3 \%)$ & $488(34.4 \%)$ & $<0.001$ \\
\hline & Low-moderate & $1094(23.4 \%)$ & $412(29.0 \%)$ & \\
\hline & Moderate-high & $1390(29.7 \%)$ & $272(19.2 \%)$ & \\
\hline & High & $1482(31.6 \%)$ & $248(17.5 \%)$ & \\
\hline \multirow[t]{4}{*}{ Educational level } & $\leq 6$ & $678(15.3 \%)$ & $580(42.6 \%)$ & $<0.001$ \\
\hline & $7-9$ & $396(8.9 \%)$ & $200(14.7 \%)$ & \\
\hline & $10-12$ & $1489(33.5 \%)$ & $358(26.3 \%)$ & \\
\hline & $\geq 13$ & $1879(42.3 \%)$ & $222(16.3 \%)$ & \\
\hline \multicolumn{5}{|l|}{ Comorbidities, $\mathrm{n}(\%)$} \\
\hline \multicolumn{2}{|l|}{ Hypertension } & $956(20.3 \%)$ & $560(39.3 \%)$ & $<0.001$ \\
\hline \multicolumn{2}{|l|}{ Dyslipidemia } & $692(14.7 \%)$ & $340(23.9 \%)$ & $<0.001$ \\
\hline \multicolumn{2}{|l|}{ Stroke } & $57(1.2 \%)$ & $71(5.0 \%)$ & $<0.001$ \\
\hline \multicolumn{2}{|l|}{ Myocardial infarction } & $99(2.2 \%)$ & $78(5.7 \%)$ & $<0.001$ \\
\hline \multicolumn{2}{|l|}{ Asthma } & $106(2.3 \%)$ & $59(4.1 \%)$ & $<0.001$ \\
\hline \multicolumn{2}{|l|}{ Diabetes mellitus } & $370(7.9 \%)$ & $255(17.9 \%)$ & $<0.001$ \\
\hline \multicolumn{2}{|l|}{ Chronic kidney disease } & $17(0.4 \%)$ & $8(0.6 \%)$ & 0.032 \\
\hline \multicolumn{2}{|l|}{ Liver cirrhosis } & $9(0.2 \%)$ & $7(0.5 \%)$ & 0.008 \\
\hline
\end{tabular}

BMI indicates body mass index; CP chewing problems.

* Body mass index was categorized into underweight $\left(<18.5 \mathrm{~kg} / \mathrm{m}^{2}\right)$, normal $\left(18.5-24.9 \mathrm{~kg} / \mathrm{m}^{2}\right)$, and obese $\left(>25.0 \mathrm{~kg} / \mathrm{m}^{2}\right)$.

씹기 불편감이 있는 참여자를 우울증 발현에 따라 평 가할 때, 씹기 불편감과 우울증이 모두 있는 (PHQ10; n $=244)$ 참여자들에서 여성이 남성보다 상대적으로 많았 다 $(P<0.001)$. 두 집단간 연령, BMI, 흡연의 유의미한 차 이는 없었다. 씹기 불편감과 우울증이 있는 참여자는 가 계 소득 $(P<0.001)$, 교육 수준이 낮았으며 $(P<0.001)$, 문제 음주를 하는 경우가 많았다 $(P=0.040$, Table 2$)$.

씹기 불편감의 위험에 대한 우울증의 영향을 분석하였
다. 단변량 분석은 우울증의 발현과 씹기 불편감 사이의 유의한 연관성을 보여주었다 $(\mathrm{OR}=1.83, P<0.001)$. 연 령, 성별 및 가구 소득, 교육 수준, 음주 빈도, 흡연, BMI, 동반질환과 같은 기타 환경 요인에 대해 조정된 모델에 서, 우울증의 발현은 여전히 씹기 불편감과 연관성이 확 인되었다(OR = 1.60, $P<0.001 ; \mathrm{OR}=1.90, P<0.001)$. 우울증의 심각도에 따른 $\mathrm{OR}$ 은 우울증 수준이 증가함 에 따라 씹기 불편감과의 연관성이 증가한다는 것을 보 
Table 2. Characteristics of chewing problem population according to presence of depression

\begin{tabular}{llccc}
\hline \multicolumn{1}{c}{ Variables } & & $\begin{array}{c}\text { Nondepression } \\
(\mathrm{n}=1181)\end{array}$ & $\begin{array}{c}\text { Depression } \\
(\mathrm{n}=244)\end{array}$ & $P / \chi^{2}$ \\
\hline Age & & $60.1(14.8)$ & $62.8(15.2)$ & 0.058 \\
Sex & Male & $551(46.7 \%)$ & $82(33.6 \%)$ & $162(66.4 \%)$ \\
& Female & $630(53.3 \%)$ & $24.0(3.8)$ & 0.574 \\
BMI* & & $24.2(3.6)$ & $140(57.4 \%)$ \\
Smoking status & Non-smoker & $638(54.0 \%)$ & $44(18.0 \%)$ \\
& Ex-smoker & $282(23.9 \%)$ & $60(24.6 \%)$ \\
Problematic Alcohol consumption & $261(22.1 \%)$ & $227(93.0 \%)$ \\
& Current smoker & $1046(88.6 \%)$ & $17(7.0 \%)$ \\
Household income & Yone & $135(11.4 \%)$ & $126(51.9 \%)$ \\
& Low & $362(30.8 \%)$ & $63(25.9 \%)$ \\
& Low-moderate & $349(29.7 \%)$ & $36(14.8 \%)$ \\
& Moderate-high & $236(20.1 \%)$ & $18(7.4 \%)$ \\
Educational level & High & $230(19.5 \%)$ & $108(59.0 \%)$ \\
& $\leq 6$ & $472(40.1 \%)$ & $32(17.5 \%)$ \\
& $7-9$ & $168(14.3 \%)$ & $26(14.2 \%)$ \\
& $10-12$ & $332(28.2 \%)$ & $17(9.3 \%)$ \\
\hline
\end{tabular}

* Body mass index was categorized into underweight $\left(<18.5 \mathrm{~kg} / \mathrm{m}^{2}\right)$, normal $\left(18.5-24.9 \mathrm{~kg} / \mathrm{m}^{2}\right)$, and obese $\left(>25.0 \mathrm{~kg} / \mathrm{m}^{2}\right)$.

Table 3. Association between depression and chewing problem using multiple logistic regression

\begin{tabular}{|c|c|c|c|c|c|c|c|c|c|}
\hline & \multicolumn{3}{|c|}{ Model 1} & \multicolumn{3}{|c|}{ Model 2} & \multicolumn{3}{|c|}{ Model 3} \\
\hline & OR & $95 \% \mathrm{CI}$ & $P$ & OR & $95 \% \mathrm{CI}$ & $P$ & OR & $95 \% \mathrm{CI}$ & $P$ \\
\hline \multicolumn{10}{|l|}{ Diagnosis of depression } \\
\hline Nondepression & 1 & & & 1 & & & 1 & & \\
\hline Depression & 1.83 & $1.55-2.16$ & $<0.001$ & 1.60 & $1.34-1.92$ & $<0.001$ & 1.90 & $1.50-2.41$ & $<0.001$ \\
\hline \multicolumn{10}{|l|}{ Levels of depression } \\
\hline None $(0-4)$ & 1 & & & 1 & & & 1 & & \\
\hline Mild (5 - 9) & 0.75 & $0.59-0.95$ & 0.015 & 0.91 & $0.71-1.18$ & 0.483 & 0.566 & $0.35-0.92$ & 0.02 \\
\hline Moderate (10 - 14) & 1.27 & $0.97-1.67$ & 0.078 & 1.84 & $1.37-2.46$ & $<0.001$ & 1.072 & $0.64-1.79$ & 0.79 \\
\hline Moderately severe (15 - 19) & 2.19 & $11.54-3.12$ & $<0.001$ & 2.82 & $1.93-4.14$ & $<0.001$ & 1.277 & $0.72-2.25$ & 0.40 \\
\hline Severe $(20-27)$ & 2.62 & $1.68-4.08$ & $<0.001$ & 2.97 & $1.83-4.82$ & $<0.001$ & 1.325 & $0.70-2.52$ & 0.39 \\
\hline
\end{tabular}

여주었다. 연령, 성별 조정 후(Model 2) 우울 정도의 증 가에 따라 씹기 불편감과 연관성의 증가가 유의미했으 나(moderate depression: adjusted $\mathrm{OR}[\mathrm{aOR}]=1.84, P$ $<0.001$; moderately severe depression: $\mathrm{aOR}=2.82, P$ $<0.001$; severe depression: $\mathrm{aOR}=2.97, P<0.001$ ), 공 변량 조정 후(Model 3) 유의한 결과를 보이지 않았다. (Table 3).

\section{고찰}

이번 연구는 씹기 불편감과 우울증의 유병률 및 심각 도 사이의 관계를 분석하였다. 일반 인구를 대상으로 총 8150명 중 19세 미만과 씹기 불편감 및 PHQ-9 조사에 응답하지 않은 참여자을 제외한 후 6128 명을 최종 분석 하였다. 분석결과 우울증의 발현이 19 세 이상인 성인들 
에서 씹기 불편감과 연관된다는 사실을 확인했다.

사회인구학적, 환경적 요인 및 동반질환에 대한 보정을 적용하고도 우울증은 씹기 불편감과 Laudisio 등의 이전 연구와 비슷한 수준의 연관성이 확인되었다(aOR: 1.90 , $95 \% \mathrm{CI}: 1.50$ - 2.41). ${ }^{2}$ 본 연구는 현재 치아나 틀니, 잇몸 등 입안의 문제로 음식을 씹는 데에 불편감을 느끼는 일 반인들을 대상으로 시행되어 참여자들은 병원에 내원하 는 환자들보다 적은 구강문제(예, 치아 파절, 치주질환, 무치악 등)를 가질 가능성이 높다는 점에서 의미가 있다. 또한, Laudisio, Kimura 등의 연구와 달리 젊은 성인을 포함한 전 연령대를 대상으로 분석했다는 점에서 차별점 이 있다.

전반적인 사회인구학적 특성들은 씹기 불편감 유무에 따른 두 그룹 간에 차이가 있었다(Table 1). 이 결과에 따 라 공변량을 보정한 다중 로지스틱 회귀분석을 이용하여 우울증과 씹기 불편감 사이의 관계를 분석하였다. 우울 증이 있는 씹기 불편감 집단은 우울증이 없는 씹기 불편 감 집단에 비해 연령, $\mathrm{BMI}$, 흡연 상태에서 차이가 없었으 나, 가계소득, 교육 수준, 문제 음주 시 유의한 차이를 보 였다(Table 2).

우울증의 발현과 씹기 불편감의 발현이 높은 관련을 보임에도 불구하고 이러한 관계를 설명하는 요소들은 아 직 명확하지 않다. 치주질환, 치아 상실, 치아 보철물 상 실, 치통, 교합되는 치아 수 감소, 구강건조증 등은 씹기 불편감에 영향을 미치는 요소들이다. ${ }^{1}$ 일부 연구에서 구 강 건강 상태와 우울증의 관련성을 확인하였다. 씹기 불 편감과 치아 상실의 가장 대표적인 원인 중 하나는 치주 질환으로, 이는 염증의 요인으로 작용할 수 있으며 염증 성 사이토카인 및 혈중 콜티솔 농도의 증가와 우울증의 연관성이 보고되었다. ${ }^{15-18}$ 또한 치통과 잇몸 출혈은 불안 과 우울증과 일으킬 수 있고, 치아 상실도 우울감과 관련 있으며 턱관절 장애 증상이 있는 경우 우울증 위험이 증 가한다는 연구도 있었다. ${ }^{16,19,20}$

본 연구에서 씹기 불편감과 우울증 사이의 연관성이 연 령이 높아짐에 따라 증가함을 보였다. 선행 연구들에서 연령이 증가할수록 씹기 능력이 감소한다는 결과를 보 였고, 노인을 대상으로 씹기 불편감과 우울감 발현의 연 관성이 확인되었다. ${ }^{2,5,921}$ 씹기 능력은 특정 음식을 씹는 데 있어 편안함과 밀접한 관련이 있으며, 이는 사람들이 먹는 음식의 종류를 선택하는데 영향을 미친다. ${ }^{21,22}$ 노인 의 치아 상실 또는 저작효율 감소는 위장장애를 유발할 수 있고, 이로 인해 부드럽고 씹기 편안한 음식을 선택하
게 되고 이는 섬유질과 비타민C, 칼슘, 단백질 등 다른 영 양소 섭취의 부족을 일으킬 수 있다. ${ }^{5,23}$ 뿐만 아니라, 식이 섭취의 변화는 체중 감소를 유발하고 암 및 심혈관 질환 과 같은 전신 질환의 위험 증가와도 연관될 수 있다. ${ }^{24}$ 따 라서 씹기 불편감은 사회적, 정서적 웰빙에 영향을 줄 수 있고, 삶의 만족도 저하에 영향을 줄 수 있으며, 절망, 슬 픔, 우울증과 같은 부정적인 감정과 관련될 수 있다. ${ }^{725}$

한편, 노인에서의 우울증은 시상하부 뇌하수체-부신 (HPA; hypothalamic-pituitary-adrenal)시스템의 기능장 애와 연관된다. ${ }^{26}$ 또한, HPA 시스템은 부신 피질에서 코 르티코스테론을 분비하게 하여 비정상적인 저작 작용을 상호 조절 하는 바, 노화와 동반된 HPA 시스템의 과활성 화는 저작 기능 장애의 위험을 높일 수 있다. ${ }^{2,27}$ 본 연구 에서는 젊은 성인을 포함한 19세 이상을 대상으로 씹기 불편감과 우울감의 관계에서 연령의 유의한 연관성을 확 인했다는 점에서 의미있다.

치료를 할 때, 치과의사들은 우울 증상이 씹기 불편감 의 위험 요소임을 인지해야 한다. 우울증 자체가 치주질 환에 대한 내성을 감소시키는 면역 기능에 부작용을 일 으킬 수 있다. ${ }^{15,17,28}$ 또한 항콜린성 작용 약물의 사용은 타 액 분비를 줄여 구강 건조증을 발생시키고 박테리아 부 착을 용이하게 하여 치아 우식증을 유발할 수 있다. ${ }^{29-31}$ 치주질환, 구강 건조증, 치아 우식 등은 씹기 불편감에 영 향을 미치는 요소들이나, 구강 문제만이 원인이 되어 씹 기 불편감이 발생하는 것은 아니며 전신적, 환경적 요인 에 의해서도 영향을 받는다. ${ }^{1,4-6}$ 일반적으로 씹기 불편감 이 있을 때, 오로지 치과적 문제만을 치료하는 경향이 있 지만, 우울증과의 상호연관성을 고려하면, 치료경과 및 예후의 향상을 위해 우울증 선별검사가 필요하다. 이번 연구에서 사용한 자가보고형 설문지는 외래환자를 대상 으로 시행하기에 유용하다. 선별검사 후 우울증이 있는 것으로 확인되면 환자들은 치과 문제에 대한 치료를 받 는 것에 추가하여 정신과적 평가를 받는 것이 추천된다. 우울증과 씹기 불편감을 종합적으로 해결해주면 치료는 더 성공적으로 이루어질 수 있다. 우울 증상을 효과적으 로 예방하거나 치료함으로써 씹기 불편감 발생률을 줄일 수 있는지 여부와 이러한 건강 상태 사이의 인과관계를 밝히기 위해서는 추가 연구가 필요하다.

본 연구에는 몇 가지 한계가 있다. 첫째로, 이 연구는 국가 건강 조사에서 얻은 데이터를 이용하여 단면적으로 조사하였기 때문에 선후 관계를 밝히거나 우울증과 씹기 불편감의 인과 관계에 대한 추론을 할 수 없었으며 오즈 
비(ORs)만 나타낼 수 있었다. 대신, 본 연구는 추가적인 종단 연구의 설계에 중요한 기초정보가 될 수 있다. 또한, 본 연구는 표본 선정시 오류의 위험을 줄이기 위해 디자 인되었으며 한국인 일반 인구로부터 조사 참여자를 구성 한 전국 조사를 기반으로 하였다. 따라서 우울증과 씹기 불편감 사이의 연관성 결과는 대표성이 있는 것으로 간 주될 수 있다. 두번째, 본 연구에서 간단한 조사를 사용 한 씹기 불편감 평가를 시행하였다. 하지만 현재 객관적 으로 씹기 불편감을 평가하기는 쉽지 않으며, 과거 자가 보고형 설문지로 씹기 불편감을 평가하여 분석한 연구도 있었다. ${ }^{47}$ 세번째, 국가 건강 설문 조사의 데이터를 사용 하여 항우울제, 대처 전략, 치과 불안(dental anxiety) 등 우울증과 씹기 불편감의 연관성에 영향을 줄 수 있는 기 타 관련 요소에 대한 중요한 정보를 탐색하지 못했다. 추 후 우울증과 씹기 불편감의 연관성을 보다 정확하게 조 사하려면, 미래의 지역 사회 기반 구강 건강 설문 조사에 서 중요한 구강 건강 위험 요인에 대한 평가가 추가로 필 요하다.

\section{결론}

이번 연구를 통해 씹기 불편감과 우울증 사이의 연관성 을 밝혔다. 우울증의 발현과 심각도는 씹기 불편감 환자 들에서 상당히 높게 나타났다. 또한, 우울증의 발현은 씹 기 불편감과 유의하게 연관 되었으며, 특히 중증의 우울 집단에서 높게 나타났다. 따라서, 씹기 불편감 환자를 평 가함에 있어 우울증의 발현은 씹기 불편감의 독립적 위 험인자로 고려되어야 하고 선별검사가 필요하다고 할 수 있다.

\section{ORCID}

Chanmo Yang https://orcid.org/0000-0002-4959-7595

Ju-Won Baek https://orcid.org/0000-0002-4459-6534

\section{References}

1. Peek CW, Gilbert GH, Duncan RP. Predictors of chewing difficulty onset among dentate adults: 24-month incidence. J Public Health Dent 2002; 62:214-21.

2. Laudisio A, Milaneschi Y, Bandinelli S, Gemma A,
Ferrucci L, Incalzi RA. Chewing problems are associated with depression in the elderly: results from the InCHIANTI study. Int J Geriatr Psychiatry 2014;29:236-44.

3. Salleh NM, Fueki K, Garrett NR, Ohyama T. Objective and subjective hardness of a test item used for evaluating food mixing ability. J Oral Rehabil 2007;34:174-83.

4. Laudisio A, Marzetti E, Antonica L, Settanni S, Georgakakis I, Bernabei R, Franceschi C, Zuccalà G. Masticatory dysfunction is associated with osteoporosis in older men. J Clin Periodontol 2007; 34:964-8.

5. Locker D. Changes in chewing ability with ageing: a 7-year study of older adults. J Oral Rehabil 2002;29:1021-9.

6. Ritchie CS, Joshipura K, Silliman RA, Miller B, Douglas CW. Oral health problems and significant weight loss among community-dwelling older adults. J Gerontol A Biol Sci Med Sci 2000;55:36671.

7. Inukai M, John MT, Igarashi Y, Baba K. Association between perceived chewing ability and oral health-related quality of life in partially dentate patients. Health Qual Life Outcomes 2010;8:118.

8. Chi I, Yip PS, Chiu HF, Chou KL, Chan KS, Kwan CW, Conwell Y, Caine E. Prevalence of Depression and Its Correlates in Hong Kong's Chinese Older Adults. Am J Geriatr Psychiatry 2005;13:409-16.

9. Kimura Y, Ogawa H, Yoshihara A, Yamaga T, Takiguchi T, Wada T, Sakamoto R, Ishimoto Y, Fukutomi E, Chen W, Fujisawa M, Okumiya K, Otsuka K, Miyazaki H, Matsubayashi K. Evaluation of chewing ability and its relationship with activities of daily living, depression, cognitive status and food intake in the community-dwelling elderly. Geriatr Gerontol Int 2013;13:718-25.

10. Kweon S, Kim Y, Jang MJ, Kim Y, Kim K, Choi S, Chun C, Khang YH, Oh K. Data resource profile: the Korea National Health and Nutrition Examination Survey (KNHANES). Int J Epidemiol 2014; 43:69-77.

11. Choi Y, Mayer TG, Williams MJ, Gatchel RJ. What is the best screening test for depression in chronic spinal pain patients? Spine J 2014;14:1175-82. 
12. de Man-van Ginkel JM, Gooskens F, Schepers VP, Schuurmans MJ, Lindeman E, Hafsteinsdóttir TB. Screening for poststroke depression using the patient health questionnaire. Nurs Res 2012;61:33341.

13. Gilbody S, Richards D, Brealey S, Hewitt C. Screening for depression in medical settings with the Patient Health Questionnaire (PHQ): a diagnostic meta-analysis. J Gen Intern Med 2007;22:1596-602.

14. Kroenke K, Spitzer RL, Williams JB. The PHQ9: validity of a brief depression severity measure. J Gen Intern Med 2001;16:606-13.

15. Johannsen A, Rylander G, Söder B, Asberg M. Dental plaque, gingival inflammation, and elevated levels of interleukin- 6 and cortisol in gingival crevicular fluid from women with stress-related depression and exhaustion. J Periodontol 2006;77:1403-9.

16. Marques-Vidal P, Milagre V. Are oral health status and care associated with anxiety and depression? A study of Portuguese health science students. J Public Health Dent 2006;66:64-6.

17. Rosania AE, Low KG, McCormick CM, Rosania DA. Stress, depression, cortisol, and periodontal disease. J Periodontol 2009;80:260-6.

18. Penninx BW, Kritchevsky SB, Yaffe K, Newman AB, Simonsick EM, Rubin S, Ferrucci L, Harris

T, Pahor M. Inflammatory markers and depressed mood in older persons: results from the Health, Aging and Body Composition study. Biol Psychiatry 2003;54:566-72.

19. Okoro CA, Strine TW, Eke PI, Dhingra SS, Balluz LS. The association between depression and anxiety and use of oral health services and tooth loss. Community Dent Oral Epidemiol 2012;40:134-44.

20. Vimpari SS, Knuuttila ML, Sakki TK, Kivelä SL. Depressive symptoms associated with symptoms of the temporomandibular joint pain and dysfunction syndrome. Psychosom Med 1995;57:439-44.

21. Onder G, Liperoti R, Soldato M, Cipriani MC, Bernabei R, Landi F. Chewing problems and mortality in older adults in home care: results from the Aged in Home Care study. J Am Geriatr Soc 2007;55: 1961-6.

22. Locker D, Matear D, Lawrence H. General health status and changes in chewing ability in older Cana- dians over seven years. J Public Health Dent 2002; 62:70-7.

23. Brodeur JM, Laurin D, Vallee R, Lachapelle D. Nutrient intake and gastrointestinal disorders related to masticatory performance in the edentulous elderly. J Prosthet Dent 1993;70:468-73.

24. Hung HC, Joshipura KJ, Jiang R, Hu FB, Hunter D, Smith-Warner SA, Colditz GA, Rosner B, Spiegelman D, Willett WC. Fruit and vegetable intake and risk of major chronic disease. J Natl Cancer Inst 2004;96:1577-84.

25. Shin HS, Ahn YS, Lim DS. Association Between Chewing Difficulty and Symptoms of Depression in Adults: Results from the Korea National Health and Nutrition Examination Survey. J Am Geriatr Soc 2016;64:270-8.

26. Holsboer F. The corticosteroid receptor hypothesis of depression. Neuropsychopharmacology 2000; 23:477-501.

27. Ono Y, Yamamoto T, Kubo KY, Onozuka M. Occlusion and brain function: mastication as a prevention of cognitive dysfunction. J Oral Rehabil 2010; $37: 624-40$.

28. Iacopino AM. Relationship between stress, depression and periodontal disease. J Can Dent Assoc 2009;75:329-30.

29. Anttila SS, Knuuttila ML, Sakki TK. Depressive symptoms favor abundant growth of salivary lactobacilli. Psychosom Med 1999;61:508-12.

30. D'Mello DA. Are your patients depressed? Implications for dental practice. J Mich Dent Assoc 2003; 85:26-32.

31. Peeters FP, deVries MW, Vissink A. Risks for oral health with the use of antidepressants. Gen Hosp Psychiatry 1998;20:150-4. 


\section{한국인에서 씹기 불편감과 우울증의 연관성: 2016 국민건강영양조사를 이용한 단면 연구}

양찬모 ${ }^{1,2}$ 전임의, 백주원 ${ }^{3 *}$ 임상조교수

${ }^{1}$ 서울대학교병원 정신건강의학과 소아청소년 정신과

${ }^{2}$ 익산시 한국 뇌행동 정신건강 연구소

3충북대학교병원 치과

목적: 본 연구는 일반 인구의 대표 표본에서 우울증의 발현과 심각도, 씹기 불편감 사이의 관계를 분석하였다.

연구 재료 및 방법: 전국 대표 표본 $(\mathrm{n}=8150)$ 을 대상으로 하였으며, 씹기 불편감은 해당 문제에 관한 설문 조사에 응답 한 사람들로 정의하였다. 우울증은 PHQ-9 설문 조사에서 총 점수가 10점 이상인 대상자로 정의하였다. 인구 통계, 사회 적 경제적 특성 및 동반 질환에 관한 데이터를 포함하여 다중 로지스틱 회귀 분석을 수행하고 분석하였다.

결과: 한국인의 경우 씹기 불편감이 없는 사람(10.2\%)보다 씹기 불편감이 있는 사람(17.2\%)에서 우울증의 유병률이 유의하게 더 높았다. 다변량 로지스틱 회귀 분석에서 우울증의 존재는 CP와 유의하게 관련 있었다(adjusted odd ratio $[\mathrm{aOR}]: 1.90, P<0.001)$. 씹기 불편감의 위험은 우울증의 심각도가 증가함에 따라 증가하였다: 중증 우울증 $(\mathrm{OR}: 2.62, P$ $<0.001)$, 중등도 우울증(OR: 2.19, $P<0.001)$.

결론: 중증 우울증을 보이는 개인에서 우울증의 공존여부가 씹기 불편감과 상당히 연관되었다. 씹기 불편감 환자 치료에 있어 우울증의 선별검사가 고려되어야 한다.

(구강회복응용과학지 2020;36(1):12-20)

주요어: 우울증; the Korea National Health and Nutrition Examination Survey (KNHANES); 씹기 불편감; 유병률; 위 험요소; 일반인구

*교신저자: 백주원

(28644) 충북 청주시 서원구 1순환로 776 , 충북대학교병원 치과

Tel: 043-269-6295 | Fax: 0504-057-5833 | E-mail: maesbaek@naver.com

접수일: 2019년 12월 11일 | 수정일: 2020년 1월 2일 | 채택일: 2020년 1월 2일 